\title{
DISTRIBUTION AND HABITAT CONDITIONS OF THE PHYTOCOENOSES OF SPHAGNUM DENTICULATUM BRIDEL AND WARNSTORFIA EXANNULATA (B., S. \& G.) LOESKE IN POLISH LOBELIA LAKES
}

\author{
MARCIN SZAŃKOWSKI, STANISŁAW KŁOSOWSKI \\ Department of Environmental Botany \\ Institute of Botany, University of Warsaw \\ Al. Ujazdowskie 4, 00-478 Warszawa, Poland \\ e-mail: m.szankowski@uw.edu.pl \\ e-mail: s.klosowski@uw.edu.pl
}

(Received: November 24, 2003. Accepted: April 7, 2004)

\begin{abstract}
Phytosociological and habitat studies of Sphagnum denticulatum and Warnstorfia exannulata phytocoenoses from Polish Lobelia lakes have been conducted. The present results were compared with data on Isoëtes lacustris community. It is demonstrated that both communities of mosses are distinct with respect to their floristic composition. Moreover, they differ significantly from the patches of I. lacustris with regard to many properties of water and substrates. The phytocoenoses of $S$. denticulatum are associated with softer waters, poorer in $\mathrm{Ca}^{2+}, \mathrm{Na}^{+}, \mathrm{NH}_{4}{ }^{+}$ and dissolved organic matter, but richer in total Fe than those of I. lacustris. They are also distinguished by lower values of electrolytic conductivity. The substrates they inhabit are more strongly hydrated and richer in organic matter, total $\mathrm{N}$, dissolved $\mathrm{SiO}_{2}, \mathrm{Ca}^{2+}$ and $\mathrm{Na}^{+}$, but poorer in $\mathrm{PO}_{4}{ }^{3-}$. The W. exannulata phytocoenoses are also confined to softer waters with lower $\mathrm{Ca}^{2+}, \mathrm{NH}_{4}{ }^{+}$and dissolved organic matter contents than those of I. lacustris. Their substrates are more strongly hydrated and have higher contents of organic matter, total $\mathrm{N}$ and $\mathrm{Na}^{+}$but lower amounts of $\mathrm{PO}_{4}{ }^{3-}$. In addition the waters of $W$. exannulata phytocoenoses are characterized by higher $\mathrm{pH}$ values and lower concentration of dissolved $\mathrm{SiO}_{2}$. The substrates are less acidic and richer in $\mathrm{NO}_{3}^{-}$, but poorer in total Fe. The differences between the habitats of the $S$. denticulatum and $W$. exannulata phytocoenoses are also distinct. The former inhabit more acidic waters, richer in dissolved $\mathrm{SiO}_{2}$ and total $\mathrm{Fe}$, but with lower values of electrolytic conductivity and concentration of $\mathrm{Na}^{+}$. Their substrates are distinguished by higher contents of organic matter and $\mathrm{Ca}^{2+}$, as well as by lower amount of $\mathrm{NO}_{3}{ }^{-}$. In view of the fact that the above phytocoenoses of mosses are distinct with respect to their floristic composition and are associated with specific habitats in which they form dense mats close to the bottom of the lake, they should be classified as distinct associations (Sphagnetum denticulati and Warnstorfietum exannulatae) in the system of aquatic communities (Class: Utricularietea intermedio-minoris).
\end{abstract}

KEY WORDS: Sphagnum denticulatum, Warnstorfia exannulata, Isoëtes lacustris, phytocoenoses, habitat conditions, Lobelia lakes, acidification.

\section{INTRODUCTION}

In most of the Lobelia lakes within the Pomeranian Lake District species considered as being typical of these lakes (mainly Lobelia dortmanna, Isoëtes lacustris, Littorella uniflora, Luronium natans, Juncus bulbosus, Myriophyllum alterniflorum) and forming in them plant communities of the class Littorelletea uniflorae are accompanied by communities of mosses which occupy the deepest waters of the littoral zone (Kraska and Piotrowicz 1994; Szmeja 1994). The latter communities were not dealt with in the classical Polish phytosociological works on Lobelia lakes (Dąmbska 1965; Ceynowa and Rejewski 1969; Kreńska 1971; Rejew- ski 1981; Boiński and Boińska 1988). Most of the authors, however, indicated the presence of various species of mosses in some of the littoral communities of these lakes. It was not until the work of Szmeja and Clément (1990) that the role of mosses in the phytocoenose structure of the associations of the class Littorelletea uniflorae in the Pomeranian Lake District was appreciated. The aforementioned authors distinguished the communities of L. uniflora-Sphagnum cuspidatum and variants with $S$. auriculatum var. auriculatum $(=S$. denticulatum) within the Isoëto-Lobelietum association. In recent years, as the number of studies on the flora and vegetation of Polish Lobelia lakes increased, more and more papers have been published which deal with 
aquatic mosses and their phytocoenoses in Lobelia and non-Lobelia lakes in the Pomerania (Gos et al. 1998; Kraska and Rusińska 1998; Szańkowski 1998 mscr; Kraska et al.1999; Gos and Banaś 1999; Banaś 2002). As a result of these investigations the following associations were recognized: Drepanocladetum tenuinervi (Kraska and Rusińska 1998) and Warnstorfietum exannulatae Szańkowski 1998 n.n. (Matuszkiewicz 2001). In spite of the fact that there was increasing interest in the massive development of moss communities, very little was known about their floristic, phytosociological and ecological differentiation, especially in Lobelia lakes. Studies on the ecology of moss communities were, therefore, initiated as a result of investigations carried out on vegetation of Polish Lobelia lakes (Szańkowski $1998 \mathrm{mscr}$ ). The necessity to undertake such studies was due to the fact that the massive development of mosses in Lobelia lakes is associated frequently with anthropogenic changes in the water habitats, among others acidification (Roelofs 1983; Vöge 1988; Arts et al. 1990; Arts and Buskens 1998; Dierssen 1998; Gos and Banaś 1999; Arts 2002), which leads to the disappearance of communities of the class Littorelletea uniflorae.

In 1994 detailed phytosociological studies were initiated which showed that the following species of mosses dominated in many of the Lobelia lakes: S. denticulatum and $W$. exannulata (=Drepanocladus exannulatus). The aforementioned species formed dense mats close to the bottom of the lake. Thus they could be recognized as the main communities of mosses in Polish Lobelia lakes. These communities were considered in the study. The main objectives of the present paper were to:

- determine the floristic composition, structure and distribution of the phytocoenoses dominated by S. denticulatum and W. exannulata,

- determine the properties of water and substrate in both moss communities studied and compare them with the data available for Isoëtes lacustris, which they often adjoin,

- compare the current findings with the data regarding the distribution and ecology of $S$. denticulatum and $W$. Exannulata, which were reported by other authors from different regions of Europe.

\section{MATERIAL AND METHODS}

The survey was carried out within the Pomeranian Lake District in the years 1994-1997 at the height of the growing season (July, August). Altogether 20 phytocoenoses of $W$. exannulata from 9 Lobelia lakes and 21 phytocoenoses of S. denticulatum from 14 Lobelia lakes were investigated. In each phytocoenose one phytosociological relevé was recorded by Braun-Blanquet method. In addition one water and one substrate sample were taken for physical and chemical analyses. Water samples were taken above the bottom within the phytocoenoses and transferred to two $1000 \mathrm{ml}$ plastic containers. Half of the samples were preserved by the addition of $1 \mathrm{ml}$ of $\mathrm{H}_{2} \mathrm{SO}_{4}$ for $\mathrm{NH}_{4}{ }^{+}, \mathrm{PO}_{4}{ }^{3-}, \mathrm{NO}_{3}{ }^{-}$total $\mathrm{Fe}$ and COD analyses. Substrate samples were taken from the rhizome root-layer with a tubular bottom sampler and transferred to plastic bags. Each sample was a mixture of a few random samples taken within a phytocoenose. Both substrate and water samples were stored at $4^{\circ} \mathrm{C}$ and analysed within a few days.
The following determinations were carried out in both water and substrate samples: $\mathrm{pH}$ (using $\mathrm{pH}$-meter), $\mathrm{NO}_{3}{ }^{-}-$ spectrophotometrically by cadmium reduction method, $\mathrm{PO}_{4}{ }^{3-}$ - spectrophotometrically by the molybdate method, $\mathrm{SO}_{4}^{2-}$ - spectrophotometrically with SulfaVer 4 reagent, dissolved $\mathrm{SiO}_{2}-$ spectrophotometrically by the heteropoly method, total $\mathrm{Fe}-$ spectrophotometrically by the rhodanate method. The concentrations of $\mathrm{Ca}^{2+}, \mathrm{Na}^{+}$and $\mathrm{K}^{+}$were estimated with a flame spectrophotometer.

Water samples were analysed for electrolytic conductivity (EC), total hardnes by titration with EDTA reagent and carbonate hardness by titration with $0.01 \mathrm{~m} \mathrm{HCl}$, chemical oxygen demand as consumption of $\mathrm{KMnO}_{4}$ in acid medium (COD), $\mathrm{NH}_{4}^{+}$by Nessler's method, $\mathrm{Cl}^{-}$by mercuric thiocyanate method. Colour was assessed spectrophotometrically according to the platinum-cobalt scale. Concentrations of $\mathrm{Na}^{+}$and $\mathrm{K}^{+}$in water were analysed in $100 \mathrm{ml}$ solutions extracted with $2 \mathrm{ml} \mathrm{1:1} \mathrm{HCl}$ from evaporated and ignited samples. Substrate samples were analysed for hydration by drying them at $105^{\circ} \mathrm{C}$ to constant weight, total $\mathrm{N}$ by Kjeldahl's method, organic matter content by ignition of dry samples at $550^{\circ} \mathrm{C}$ for $1.5 \mathrm{~h}$. The ion concentrations were

TABLE 1. A synoptic table of the vegetation data studied. IL - community of Isoëtes lacustris; WE - community of Warnstorfia exannulata; SD community of Sphagnum denticulatum. Constancy: r-0-5\%; + - 5-10\%; I - 10-20\%; II - 20-40\%; III - 40-60\%; IV - 60-80\%; V - 80-100\%. Accompanying species are not displayed.

\begin{tabular}{|c|c|c|c|}
\hline Community type & IL & WE & SD \\
\hline Number of relevés & 22 & 20 & 21 \\
\hline Number of lakes & 17 & 9 & 14 \\
\hline \multicolumn{4}{|l|}{ Character or dominant species: } \\
\hline Isoëtes lacustris & $V^{3-5}$ & $\mathrm{II}^{+-2}$ & $+{ }^{1-2}$ \\
\hline Warnstorfia exannulata & $\mathrm{r}^{1}$ & $V^{4-5}$ & $\mathrm{II}^{+-3}$ \\
\hline Sphagnum deenticulatum & $\mathrm{II}^{+-2}$ & $\mathrm{II}^{+-2}$ & $V^{4-5}$ \\
\hline \multicolumn{4}{|l|}{ Character species of the class Littorelletea } \\
\hline Myriophyllum alterniflorum & $\mathrm{III}^{+-3}$ & $\mathrm{II}^{+-1}$ & \\
\hline Nitella flexilis & $\mathrm{II}^{+-1}$ & $+^{+-3}$ & $\mathrm{I}^{+-1}$ \\
\hline Littorella uniflora & $\mathrm{II}^{+-1}$ & & \\
\hline Lobelia dortmanna & $\mathrm{II}^{+}$ & & \\
\hline Luronium natans & $+^{+-1}$ & & \\
\hline Chara delicatula & $+^{+}$ & & \\
\hline Sparganium $x$ diversifolium & $\mathrm{r}^{+}$ & & \\
\hline Sparganium angustifolium & $\mathrm{r}^{+}$ & & \\
\hline \multicolumn{4}{|l|}{ Character species of the class Potametea } \\
\hline Callitriche hamulata & $r^{2}$ & $\mathrm{r}^{+}$ & \\
\hline Elodea canadensis & $\mathrm{r}^{+}$ & $\mathrm{I}^{+-1}$ & \\
\hline Potamogeton obtusifolius & & $\mathrm{I}^{+-1}$ & \\
\hline Ceratophyllum demersum & & $\mathrm{I}^{+}$ & \\
\hline Potamogeton acutifolius & & +1 & \\
\hline Nymphaea candida & & $\mathrm{r}^{+}$ & \\
\hline Potamogeton crispus & & $\mathrm{r}^{+}$ & \\
\hline Potamogeton praelongus & & $\mathrm{r}^{+}$ & \\
\hline Potamogeton bertholdi & $\mathrm{r}^{+}$ & & \\
\hline \multicolumn{4}{|l|}{ Bryophytes } \\
\hline Fontinalis antipyretica (sensu lato) & $\mathrm{II}^{1-2}$ & $\mathrm{II}^{+-3}$ & $\mathrm{r}^{2}$ \\
\hline Warnstorfia fluitans & $\mathrm{II}^{+-3}$ & $r^{3}$ & $\mathrm{I}^{1-4}$ \\
\hline Chiloscyphos polyanthos & $\mathrm{r}^{3}$ & & $\mathrm{r}^{1}$ \\
\hline Riccardia multifida & $\mathrm{r}^{3}$ & & \\
\hline Fontinalis dalecarlica & $r^{1}$ & & \\
\hline Drepanocladus tenuinervis & & $+^{+}$ & \\
\hline Warnstorfia trichophylla & & & $\mathrm{r}^{+}$ \\
\hline
\end{tabular}


determined in solutions extracted from the substrate samples. The solutions were obtained from fresh samples containing $1 \mathrm{~g}$ of dry matter by addition of $100 \mathrm{ml}$ of demineralized water. In the case of solutions used for determinations of $\mathrm{Ca}^{2+} \mathrm{SO}_{4}{ }^{2-}, \mathrm{PO}_{4}{ }^{3-}$ and total $\mathrm{Fe}$ each sample was first dissolved in $20 \mathrm{ml} \mathrm{1:1} \mathrm{HCl}$ within $2 \mathrm{~h}$. After $24 \mathrm{~h}$ the dissolved samples were $3 \mathrm{~m}$-paper filtered, rinsed with small amounts of demineralized water and the quantity of the extracted solutions was adjusted to $250 \mathrm{ml}$. Contents of $\mathrm{Na}^{+}$and $\mathrm{K}^{+}$in substrate were assessed in $100 \mathrm{ml}$ solutions extracted with $2 \mathrm{ml} \mathrm{1:1} \mathrm{HCl}$ from dried and ignited samples.

The phytocoenoses of $S$. denticulatum and $W$. exannulata were compared with 22 phytocoenoses of Isoëtes lacustris previously investigated in the Pomeranian Lake District (Szańkowski and Kłosowski 1996). The multivariate vegetation-habitat relationships were analysed by means of Canonical Correspondence Analysis (CCA) using CANOCO for Windows Version 4.0 (Ter Braak and Šmilauer 1998). Two sets of data were analysed separately: phytocoenoses - water properties and phytocoenoses - substrate properties. Moreover, the habitat conditions of the communities studied were compared with respect to each property using quartiles. The significance of differences between the water and substrate properties of the phytocoenoses investigated was determined by one-way analysis of variance and the Newman-Keuls test (Zar 1984). The $\mathrm{pH}$ values were recalculated so as to obtain $\mathrm{H}^{+}$concentration.

\section{RESULTS}

Phytosociological characteristics of the phytocoenoses studied and their distribution within the lakes
Phytosociological analysis of the phytocoenoses of $S$. denticulatum and $W$. exannulata (Table 1) showed that they occurred in dense stands. The floristic poverty of the aforementioned phytocoenoses was attributed to the floristic dominance of the species forming these phytocoenoses. This mainly applied to the patches with $S$. denticulatum, in which only $W$. exannulata played an important role in the community structure (II constancy class) and where the mean number of species in a relevé was 2 . Among the representatives of the class Littorelletea uniflorae, the following species were found to occur rarely in the S. denticulatum phytocoenoses: I. lacustris and Nitella flexilis. The contribution of Warnstorfia. fluitans was much higher in 3 patches only.

The phytocoenoses of $W$. exannulata were richer in species (on average 4 species in a relevé). They were characterized by a higher proportion of species representing the class Littorelletea uniflorae, e.g. M. alterniflorum and I. lacustris (II constancy class). Such species as N. flexilis and Sparganium angustifolium were noted occasionally. Among mosses Fontinalis antipyretica and S. denticulatum were also encountered (II constancy class). The presence of Potametea species (e.g. Potamogeton obtusifolius, Elodea canadensis and Ceratophyllum demersum) was recorded in some of the phytocoenoses studied.

The I. lacustris phytocoenoses had a higher frequency of the following Littorelletea species: $M$. alterniflorum (III constancy class), L. dortmanna, L. uniflora and N. flexilis (II constancy class). Luronium natans, Chara delicatula and Sparganium $\mathrm{x}$ diversifolium were recorded more rarely. Among mosses $S$. denticulatum, $W$. fluitans, and $F$. antipyretica, were encountered (II constancy class). In the individual phytocoenoses the following species of liverworts

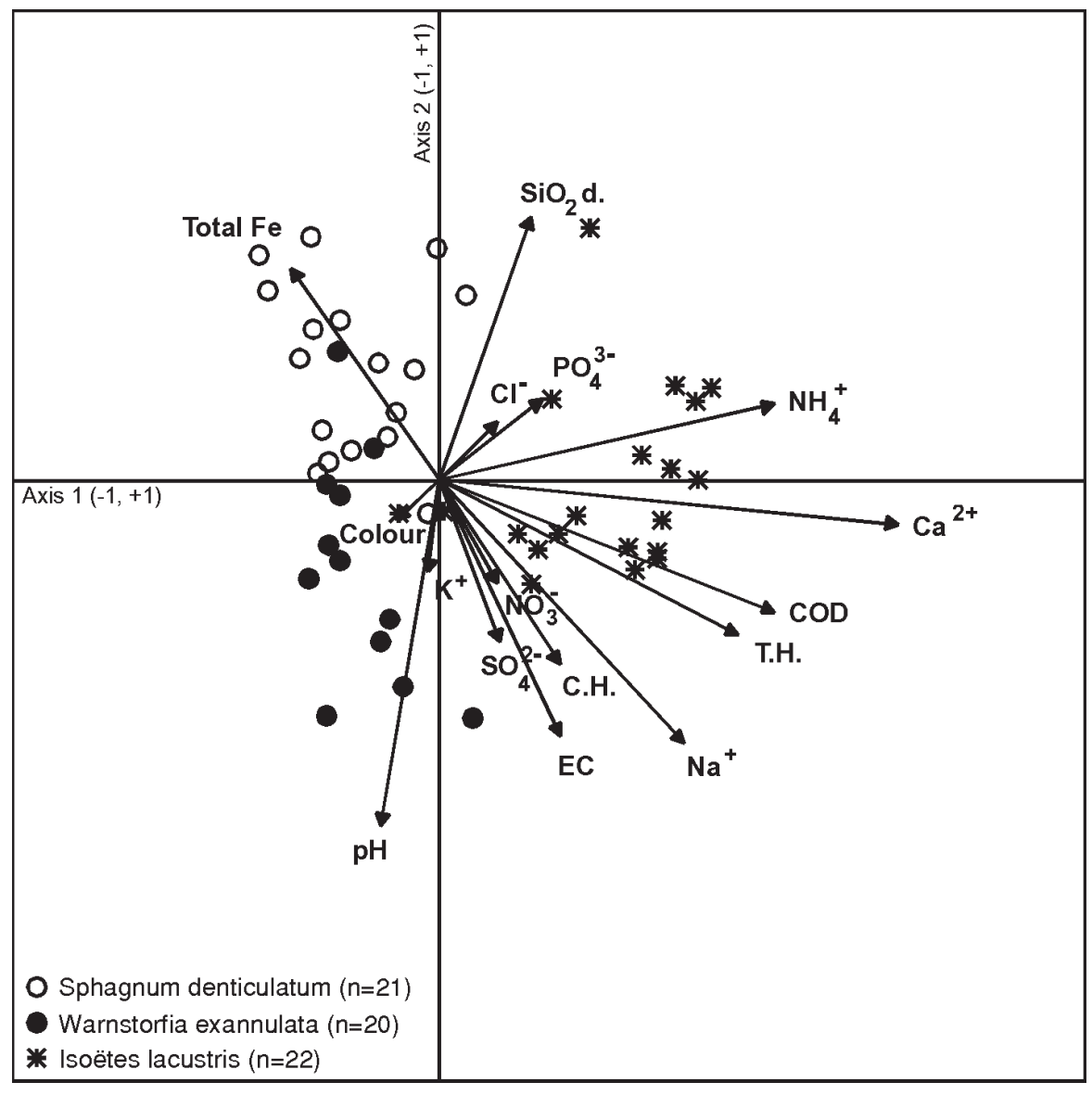

Fig. 1. CCA ordination diagram of $1^{\text {st }}$ and $2^{\text {nd }}$ axes based on 16 properties of water and 63 relevés. Eigenvalues: $\lambda 1=0.72, \lambda 2=0.44$, $\lambda 3=0.16, \lambda 4=0.11, \Sigma \lambda=3.94$. The overlapping relevés could not be displayed. EC - electrolytic conductivity; T.H. - total hardness; C.H. - carbonate hardness; $\mathrm{SiO}_{2}$ d. $-\mathrm{SiO}_{2}$ dissolved; $\mathrm{COD}$ - chemical oxygen demand. 
$\mathrm{pH}$

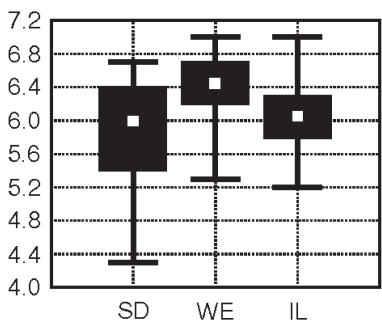

Total hardness

[mval/n]

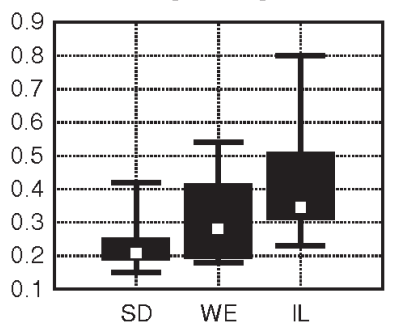

$\mathrm{NH}_{4}^{+}[\mathrm{mg} / \mathrm{l}]$

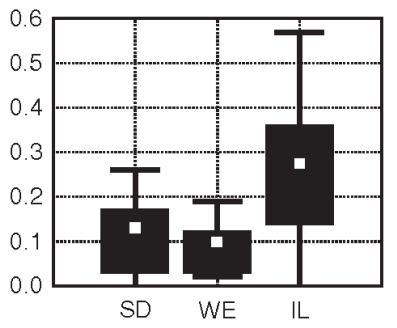

$\mathrm{SiO}_{2}$ dissolved [mg/l]

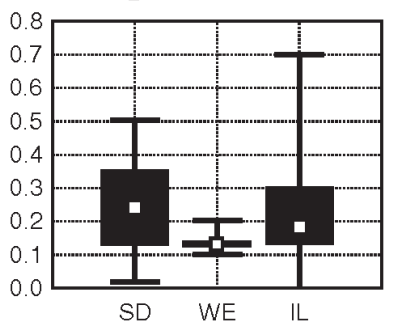

Colour [mg Pt/]

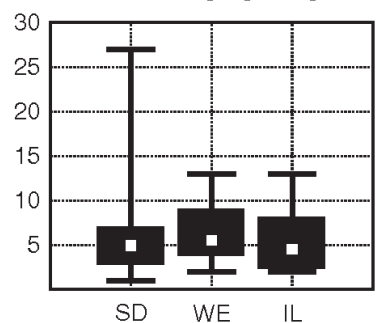

Carbonate hardness [mval/l]

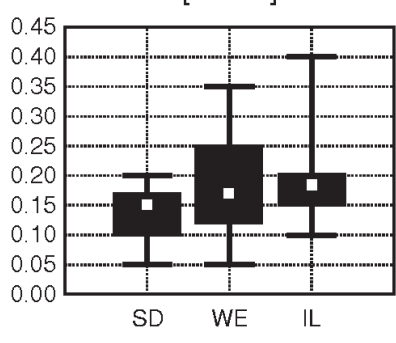

$\mathrm{K}^{+}[\mathrm{mg} / \mathrm{l}]$

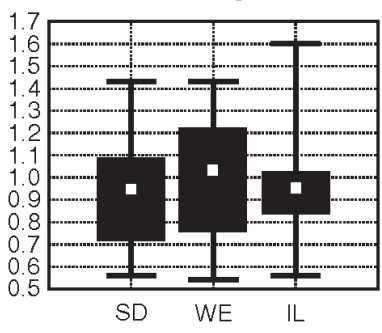

Total Fe [mg/l]

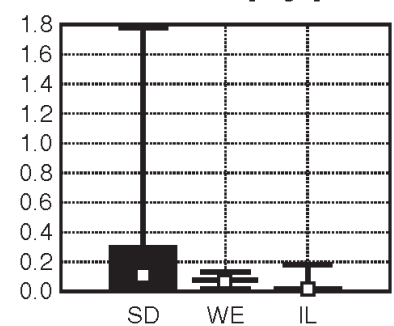

Chemical oxygen demand $\left[\mathrm{mg} \mathrm{O}_{2} / \mathrm{l}\right]$

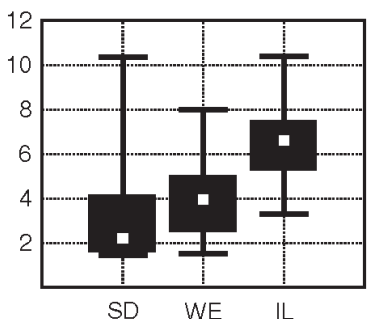

$\mathrm{Ca}^{2+}[\mathrm{mg} / \mathrm{l}]$

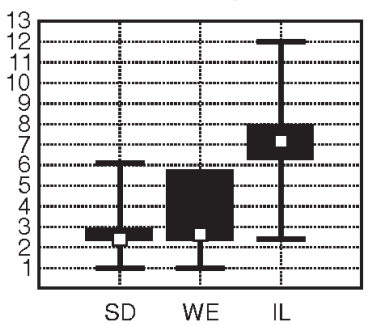

$\mathrm{PO}_{4}^{3-}[\mathrm{mg} / \mathrm{l}]$

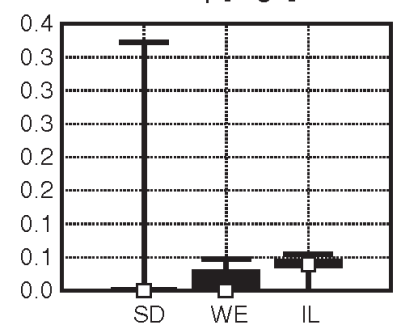

$\mathrm{Na}^{+}[\mathrm{mg} /]$

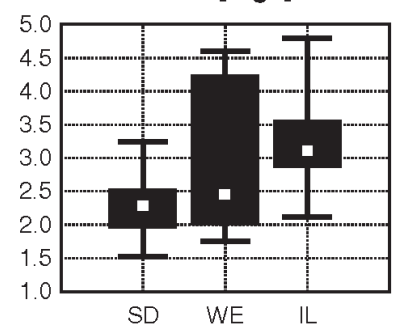

Electrolytic conductivity $\left[\mu \mathrm{S} / \mathrm{cm}\right.$ at $\left.20^{\circ} \mathrm{C}\right]$

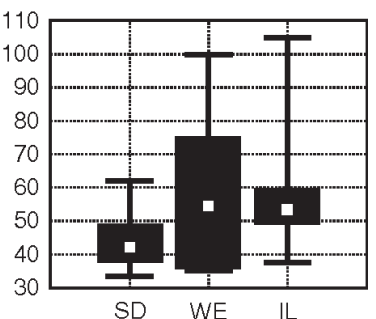

$\mathrm{SO}_{4}^{2-}[\mathrm{mg} / \mathrm{l}]$

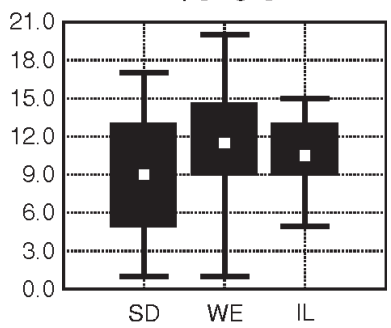

$\mathrm{NO}_{3}^{-}[\mathrm{mg} / \mathrm{l}]$

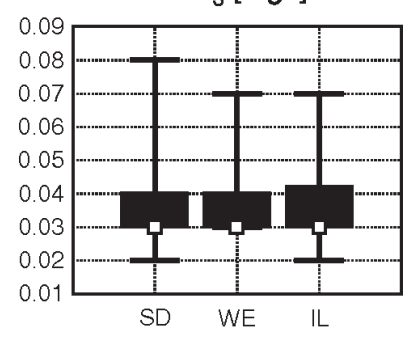

$\mathrm{Cl}^{-}[\mathrm{mg} / \mathrm{I}]$

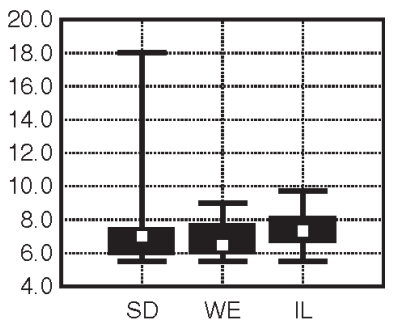

Fig. 2. Variability of 16 properties of water in the phytocoenoses studied. Black boxes display $25-75 \%$ interquartile ranges of values and white boxes show the medians. Groups of phytocoenoses dominated by: SD - Sphagnum denticulatum $(\mathrm{n}=21)$, WE - Warnstorfia exannulata $(\mathrm{n}=20)$, IL - Isoëtes lacustris $(n=22)$.

played an important role: Chiloscyphos polyanthos and Riccardia multifida.

The above floristic composition of the phytocoenoses analysed reflects their spatial distribution in the Lobelia lakes studied. The patches with S. denticulatum, being the poorest in species, occur in the deepest layers (about $7 \mathrm{~m}$ ) of the lake, which receive less light. They usually develop at a depth of 2.5-4.5 m, inhabiting the upper, highly hydrated layers of the organic substrates. The phytocoenoses of $W$. exannulata are found at $5.5 \mathrm{~m}$. They attain their optimum development at the depth range of $2.8-3.9 \mathrm{~m}$ on $\mathrm{mi}-$ neral-organic and organic bottoms. The patches of I. lacustris occur in waters down to $5 \mathrm{~m}$. They usually develop at a depth ranging from $1.0 \mathrm{~m}$ to $2.5 \mathrm{~m}$. In most cases the phytocoenoses of I. lacustris adjoin those of mosses at the lower limit of their vertical range of distribution. In some lakes they border the $W$. exannulata phytocoenoses, in others the I. lacustris phytocoenoses adjoin the patches of $S$. denticulatum. The above phytocoenoses of mosses rarely neighbour one another in the same lake.

\section{Habitat properties of the phytocoenoses studied}

Considerable differences between the water habitats of the phytocoenoses studied were found regarding $\mathrm{Ca}^{2+}$ concentration. This variable is strongly correlated with the first ordination axis which separates the water habitats of the $I$. lacustris phytocoenoses from those of the communities of mosses (Fig. 1). The lowest concentration of $\mathrm{Ca}^{2+}$ (mainly 2.5-2.9 $\mathrm{mg} / \mathrm{l}$ ) was found in the water of the $S$. denticulatum phytocoenoses (Fig. 2) with higher levels in that of $W$. exannulata $(2.2-5.8 \mathrm{mg} / \mathrm{l})$ and the highest in that of $I$. lacustris phytocoenoses $(6.2-8.0 \mathrm{mg} / \mathrm{l})$. A similar trend was observed in the case of other properties of water which are correlated with the first ordination axis: chemical oxygen 
TABLE 2. Significance of differences in water and substrate properties between the three communities studied. + - significant at $\mathrm{P} \leq 0.05$; ns non-significant at $\mathrm{P} \leq 0.05$. Symbols of communities - see Table 1 .

\begin{tabular}{|c|c|c|c|}
\hline Properties of water & IL-WE & IL-SD & WE-SD \\
\hline $\mathrm{Ca}^{2+}$ & + & + & ns \\
\hline Total hardness & + & + & ns \\
\hline COD-KMnO 4 & + & + & ns \\
\hline $\mathrm{NH}_{4}^{+}$ & + & + & ns \\
\hline $\mathrm{pH}$ & + & ns & + \\
\hline $\mathrm{SiO}_{2}$ dissolved & + & ns & + \\
\hline $\mathrm{Na}^{+}$ & ns & + & + \\
\hline Electrolytic conductivity & ns & + & + \\
\hline Total Fe & $\mathrm{ns}$ & + & + \\
\hline Carbonate hardness & ns & + & ns \\
\hline Colour & ns & ns & ns \\
\hline $\mathrm{SO}_{4}^{2-}$ & ns & ns & ns \\
\hline $\mathrm{PO}_{4}^{3-}$ & $\mathrm{ns}$ & ns & ns \\
\hline $\mathrm{Cl}^{-}$ & ns & ns & ns \\
\hline $\mathrm{K}^{+}$ & ns & ns & ns \\
\hline $\mathrm{NO}_{3}^{-}$ & ns & ns & ns \\
\hline Properties of substrate & IL-WE & IL-SD & WE-SD \\
\hline Hydration & + & + & $\mathrm{ns}$ \\
\hline Organic matter & + & + & + \\
\hline Total N & + & + & $\mathrm{ns}$ \\
\hline $\mathrm{PO}_{4}^{3-}$ & + & + & ns \\
\hline $\mathrm{Na}^{+}$ & + & + & ns \\
\hline $\mathrm{NO}_{3}^{-}$ & + & ns & + \\
\hline $\mathrm{Ca}^{2+}$ & ns & + & + \\
\hline $\mathrm{pH}$ & + & ns & ns \\
\hline Total Fe & + & ns & $\mathrm{ns}$ \\
\hline $\mathrm{SiO}_{2}$-dissolved & $\mathrm{ns}$ & + & ns \\
\hline $\mathrm{SO}_{4}^{2-}$ & ns & ns & ns \\
\hline $\mathrm{K}^{+}$ & ns & ns & ns \\
\hline
\end{tabular}

demand (COD) and total hardness. Similar results were also obtained for $\mathrm{NH}_{4}{ }^{+}$(Figs 1 and 2) in waters inhabited by the I. lacustris phytocoenoses.

The second ordination axis clearly separates the water habitats of $S$. denticulatum from those of $W$. exannulata and is correlated with $\mathrm{pH}$, electrolytic conductivity (EC), dissolved $\mathrm{SiO}_{2}$, total $\mathrm{Fe}$ and $\mathrm{Na}^{+}$concentration (Fig. 1). The three communities analysed in this study are associated with acidic waters (Fig. 2). The phytocoenoses of S. denticulatum developed best in the most acidic waters (mostly at $\mathrm{pH}$ 5.3-6.3), whereas those of $W$. exannulata showed preference for slightly acid waters (mainly $\mathrm{pH}$ 6.2-6.7) and differed significantly from the other phytocoenoses in the case of $\mathrm{pH}$ (Table 2). With regard to this property the I. lacustris phytocoenoses occupy an intermediate position (5.8-6.3 pH). The highest concentration of total Fe was recorded in the $S$. denticulatum dominated phytocoenoses. The latter community (like the patches of I. lacustris) developed in waters rich in dissolved $\mathrm{SiO}_{2}$ (Figs 1 and 2) but with significantly lower concentration of $\mathrm{Na}^{+}$and lower value of electrolytic conductivity than the other types of phytocoenoses studied (see Table 2). The patches with $W$. exannulata were associated with waters having the lowest concentration of dissolved $\mathrm{SiO}_{2}$ (significantly different values from those obtained for the other types of phytocoenoses studied - see Table 2) and relatively poor in total Fe, but rich in $\mathrm{Na}^{+}$(Figs 1 and 2). The remaining properties (colour, $\mathrm{Cl}^{-}, \mathrm{SO}_{4}^{2-}$ and those indicating water richness: $\left.\mathrm{PO}_{4}{ }^{3-}, \mathrm{NO}_{3}{ }^{-}, \mathrm{K}^{+}\right)$appeared to be less important in differentiating the water habitats of the phytocoenoses studied.
The substrates differentiated the habitats of the three types of phytocoenoses studied to a similar degree as water. The first ordination axis clearly separates the substrates of I. lacustris from those of the phytocoenoses of mosses and is strongly correlated with hydration, organic matter content, total $\mathrm{N}$ and $\mathrm{PO}_{4}{ }^{3-}$ (Fig. 3). These properties are most important in differentiating the habitats compared. In the case of the first three properties, the highest values were recorded for the substrates inhabited by the $S$. denticulatum phytocoenoses, lower for the patches with $W$. exannulata and the lowest for those of I. lacustris (Fig. 4). With regard to these three properties, the differences between the substrates of I. lacustris phytocoenoses and the two moss communities are significant (Table 2). A reverse tendency was observed in the case of $\mathrm{PO}_{4}{ }^{3-}$. From Figures 3 and 4, it is clear that the substrates of the moss communities are markedly poorer in $\mathrm{PO}_{4}^{3-}$ than those of I. lacustris (see Table 2). A similar trend as in the case of hydration, total N, and organic matter content was noted for dissolved $\mathrm{SiO}_{2}$ and $\mathrm{Ca}^{2+}$ (Fig. 3). The highest levels of the above properties were noted in the substrates of S. denticulatum and the lowest levels in that of I. lacustris (significant differences were marked - Table 2). The substrates of $W$. exannulata occupy an intermediate position with regard to the aforementioned properties (Fig. 4).

Other properties, such as $\mathrm{Na}^{+}$and total $\mathrm{Fe}$, which are correlated with the first ordination axis (Fig. 3), differentiated the substrates of the phytocoenoses studied as well. The highest content of $\mathrm{Na}^{+}$was observed in the substrates of the $W$. exannulata phytocoenoses and the lowest in that of I. lacustris. A reverse tendency was observed in the case of total Fe content. The highest content of total Fe was noted in the substrates of I. lacustris phytocoenoses and the lowest in that of $W$. exannulata (Fig. 4). Significant differences between the above types of phytocoenoses were found regarding these two properties (Table 2). The substrates of $S$. denticulatum patches occupy an intermediate position (Fig. 4). In the case of $\mathrm{Na}^{+}$significant differences were marked between the phytocoenoses of I. lacustris and those of mosses (with regard to total Fe the differences are significant only between the phytocoenoses of I. lacustris and those of W. exannulata - see Table 2).

\section{DISCUSSION}

The results obtained in the present study indicated that the phytocoenoses of mosses analysed in this study differed significantly from I. lacustris phytocoenoses with respect to many properties of water (e.g. $\mathrm{Ca}^{2+}$, total hardness, COD, $\mathrm{NH}_{4}^{+}$), and substrate (e.g. organic matter, total $\mathrm{N}$, hydration, $\mathrm{PO}_{4}{ }^{3-}, \mathrm{Na}^{+}$). Considerable differences between the habitats of $S$. denticulatum and $W$. exannulata phytocoenoses were also found. The properties which sharply differentiated the water habitat of $S$. denticulatum from that of $W$. exannulata were $\mathrm{pH}$, dissolved $\mathrm{SiO}_{2}, \mathrm{Na}^{+}$, electrolytic conductivity and total $\mathrm{Fe}$, and in the case of substrates organic matter content, $\mathrm{Ca}^{2+}$ and $\mathrm{NO}_{3}{ }^{-}$. In addition (although the differences were not statistically significant) the waters of $S$. denticulatum phytocoenoses were softer and poorer in $\mathrm{Ca}^{2+}$ and dissolved organic matter than those of $W$. exannulata. In many cases the substrates inhabited by $S$. denticulatum were more acidic and strongly hydrated. 


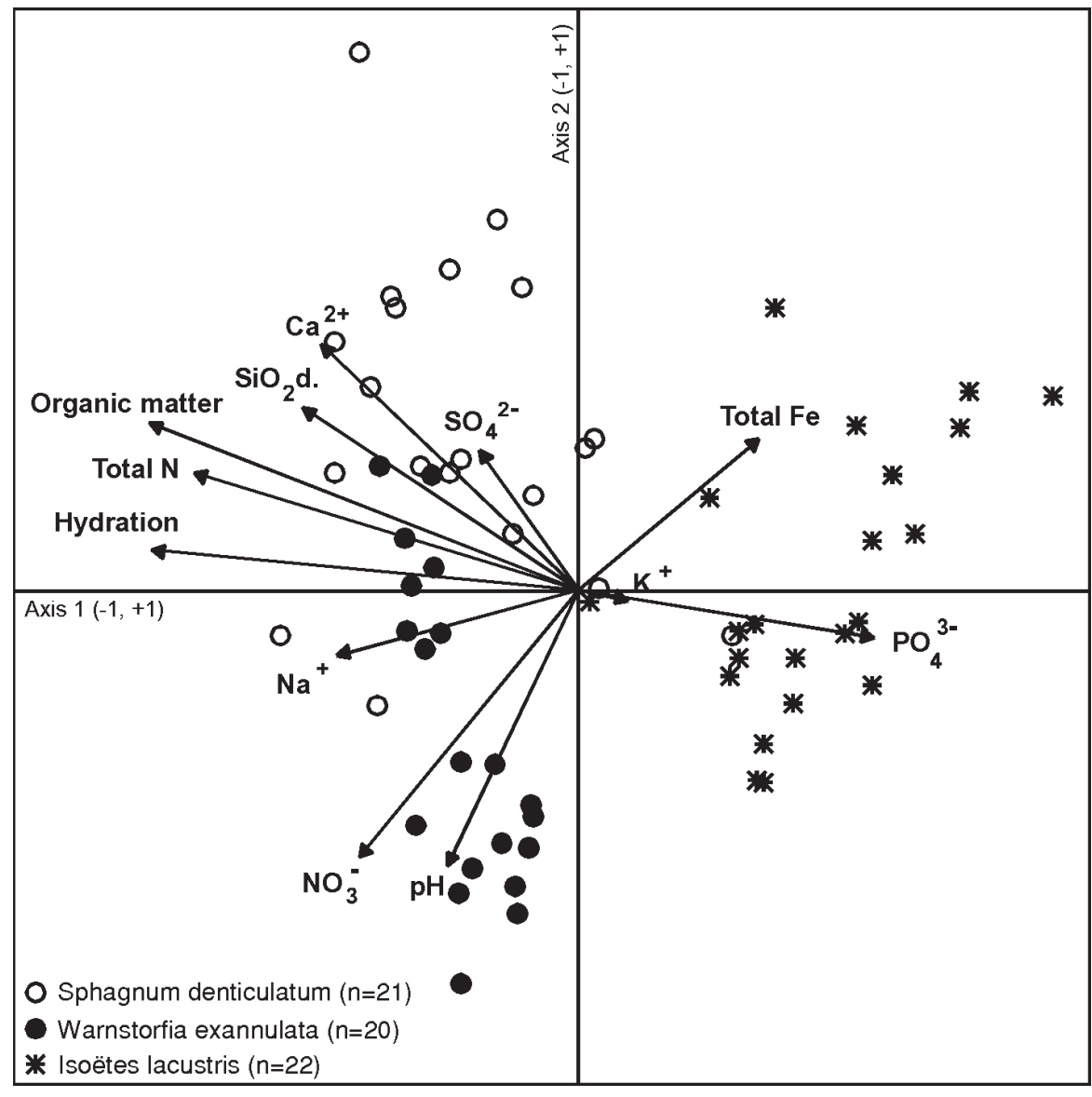

Fig. 3. CCA ordination diagram of $1^{\text {st }}$ and $2^{\text {nd }}$ axes based on 12 properties of substrate and 63 relevés. Eigenvalues: $\lambda 1=0.71$, $\lambda 2=0.39, \lambda 3=0.11, \lambda 4=0.09, \Sigma \lambda=3.94$. The overlapping relevés could not be displayed. $\mathrm{SiO}_{2}$ d. $-\mathrm{SiO}_{2}$ dissolved.
They were also distinguished by a higher total $\mathrm{N}$ content. It appears that both communities of the studied mosses could be good indicators of the littoral habitat conditions. The importance of mosses as limnological indicators, especially in lakes undergoing acidification, was pointed out by various authors, e.g. Grahn (1977), Arts (1990). The invasion of lakes by various Sphagnum species, including S. denticulatum $(=S$. auriculatum), was observed with increasing acidification of their waters (e.g. Roelofs 1983; Roberts et al. 1985; Raven 1988; Arts 1990, 2002; Arts and Buskens 1998; Dierssen 1998).

The present study revealed the association of S. denticulatum phytocoenoses with acidic habitats, which is in agreement with the findings of the aforementioned authors. However the range of $\mathrm{pH}$ values most frequently noted in the water of the $S$. denticulatum phytocoenoses from Lobelia lakes analysed in this study lies within higher values (5.4-6.4) compared to that of the waters from other regions of Europe, which are subject to acidification as well. In the case of 4 phytocoenoses, the $\mathrm{pH}$ of water was, however, below 5.4 and within the $\mathrm{pH}$ range of 4.3-5.3. In Denmark S. denticulatum occurred mainly at $\mathrm{pH}$ 4.5-5.5 (Soerensen 1948). In other West European countries, e.g. Holland and Scotland, the lakes affected by acidification were inhabited by the $S$. denticulatum phytocoenoses developing in the $\mathrm{pH}$ range of 4.4-5.0, (Arts 1990) and 4.5-5.0 (Raven 1988), respectively. In Poland such low values of $\mathrm{pH}$ in the $S$. denticulatum habitat have been recorded mainly in acidic waters of non-Lobelia lakes (Banaś 2002). These differences may have been attributed to the fact that many of the Polish Lobelia lakes inhabited by $S$. denticulatum are subject to natural acidification, which is related to the nature of the catchment area and dominance of pine forests and acidophilic deciduous forests developing beside the lakes. Compared with the rapidly proceeding process of acidification of lakes in Western Europe caused mainly by human activities e.g. acid rains (Grahn 1977; Evans 1984; Arts et al. 1990; Arts and Buskens 1998), the acidification process taking place in many of the Polish Lobelia lakes has been reported to proceed at a slower rate and leads gradually to the dystrophy of the lakes (Szmeja 1997; Gos et al. 1998; Gos and Banaś 1999; Kraska et al. 1999). Under natural conditions the slow process of dystrophy is favourable for the coexistence of typical isoetid species with the phytocoenoses of mosses, which occupy the deepest layers of the littoral zone. This mainly applies to I. lacustris, of which the phytocoenoses often adjoin those of $S$. denticulatum and $W$. exannulata. These observations were made in most of the Lobelia lakes investigated by the authors. The data obtained by various authors (e.g. Kohler and Schoen 1984; Raven 1988; Arts et al. 1990; Kraska et al. 1998) indicate that I. lacustris is highly tolerant of acid waters. The present findings are in agreement with the data of the aforementioned authors and those relating to substrate properties. It was found that the substrates of most I. lacustris phytocoenoses were more acidic than those of $S$. denticulatum and W. exannulata. At present the phytocoenoses of $I$. lacustris are not endangered by the natural process of dystrophy taking place in many of the Lobelia lakes as the process is not in its final stage. Some authors (Szmeja et al. 2001; Banaś 2002) indicate that humic substances, which are released into the lakes due to human activities in the catchment area, can threaten the vegetation of Lobelia lakes, including the $S$. denticulatum phytocoenoses. The in- 
$\mathrm{pH}$

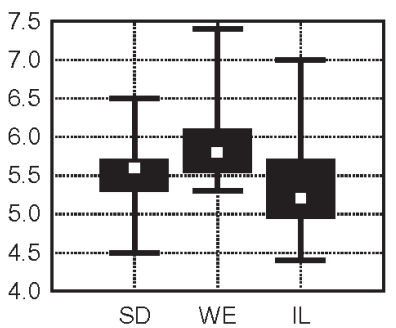

$\mathrm{K}^{+}[\mathrm{g} / \mathrm{kg}$ dry matter $]$

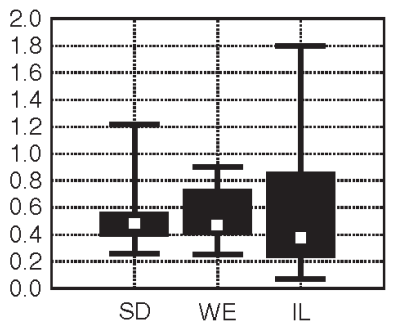

$\mathrm{Ca}^{2+}[\mathrm{g} / \mathrm{kg}$ dry matter]

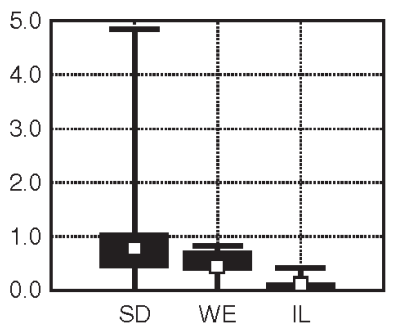

Hydration [\%]

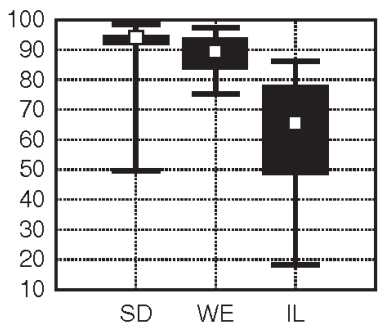

$\mathrm{Na}^{+}[\mathrm{g} / \mathrm{kg}$ dry matter]

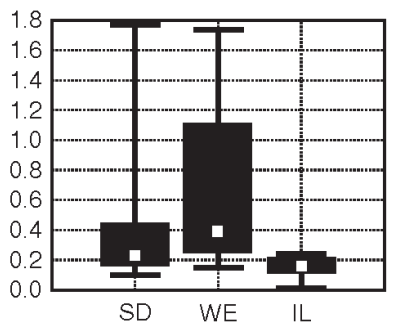

Total Fe [g/kg dry matter]

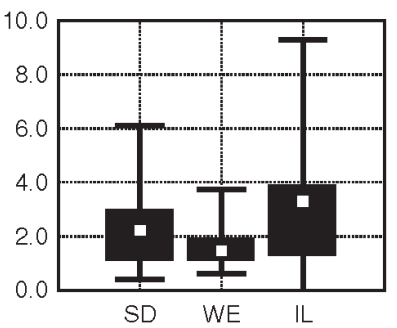

Organic matter [\% dry matter]

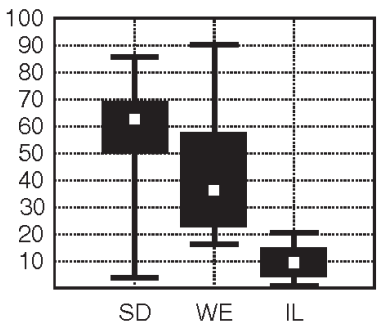

$\mathrm{PO}_{4}^{3-}[\mathrm{g} / \mathrm{kg}$ dry matter $]$

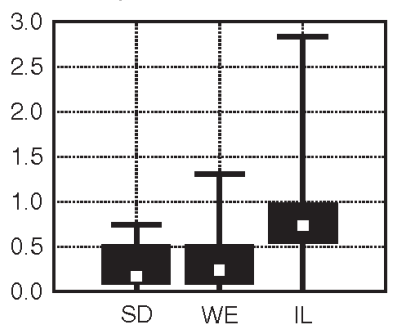

$\mathrm{SO}_{4}^{2-}[\mathrm{g} / \mathrm{kg}$ dry matter]

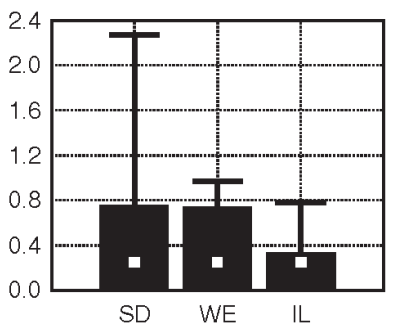

Total $\mathrm{N}[\mathrm{g} / \mathrm{kg}$ dry matter]

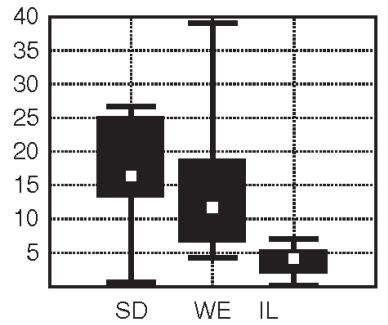

$\mathrm{NO}_{3}^{-}[\mathrm{g} / \mathrm{kg}$ dry matter]

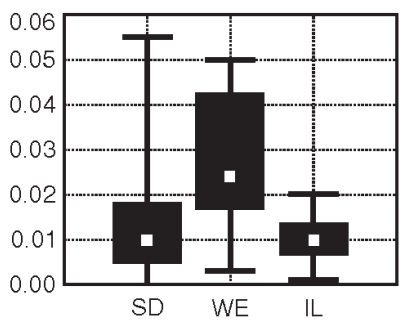

$\mathrm{SiO}_{2}$ dissolved $[\mathrm{g} / \mathrm{kg}$ dry matter]

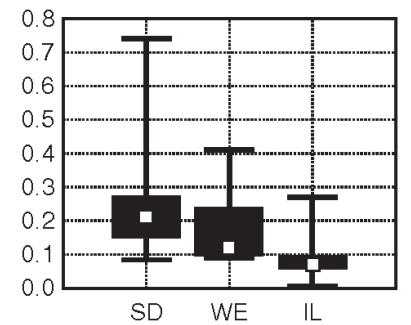

Fig. 4. Variability of 12 properties of substrate in the phytocoenoses studied. Black boxes display $25-75 \%$ interquartile ranges of values and white boxes show the medians. Groups of phytocoenoses dominated by: SD - Sphagnum denticulatum $(\mathrm{n}=21)$, WE - Warnstorfia exannulata $(\mathrm{n}=20)$, IL - Isoëtes lacustris $(\mathrm{n}=22)$.

flow of humic substances leads to an increase in the colour of water and results in the retreat and, subsequently, elimination of the plant communities from the deeper parts of the lake littoral.

Most data obtained from different regions of Europe point to a relatively wide ecological amplitude of $W$. exannulata (especially in the case of $\mathrm{pH}$ of water). Sörensen (1948) demonstrated that $W$. exannulata occurred mainly in water with $\mathrm{pH}$ 4.5-6.5, Malme (1978): 5.6-7.2 pH, and Karttunen and Toivonen (1995): 5.5-8.1. The above findings indicate that $W$. exannulata is associated with less acidic habitats than $S$. denticulatum. The present study confirms these observations made in the case of both water and substrate. It appears, therefore, that the phytocoenoses of W. exannulata cannot be regarded as indicators of the progressing dystrophy of the Lobelia lakes, as opposed to those of $S$. denticulatum.

It is interesting to note that the three studied communities differed from each other with respect to their substrate and water properties to a similar degree. This fact is of great importance, as in the case of moss communities the chemistry of water is usually analysed, which is considered to be their main source of nutrients (Malme 1978; Brandrud and Johansen 1994). The present study showed that the phytocoenoses of the mosses analysed, particularly those dominated by $S$. denticulatum, were associated mainly with substrates rich in organic matter. Some authors, however, claim that most aquatic mosses avoid highly organic sub- strates (e.g. Sörensen 1948). Malme (1978) suggested that mosses developed best on mineral-organic bottoms and that the thick layer of slightly decomposed organic substrate (more than $50 \mathrm{~cm}$ thick) restricts their occurrence. The current findings showed that in the case of the phytocoenoses of $S$. denticulatum and $W$. exannulata the layer of organic substrate did not exceed $50 \mathrm{~cm}$. The substrates were, however, highly decomposed and hydrated. Thus strongly hydrated substrates just like water could constitute the source of nutrients for such species as S. denticulatum and W. exannulata.

The differences between the substrates of the phytocoenoses of I. lacustris and the phytocoenoses of mosses could be associated with the fact that the patches with $I$. lacustris occupy shallower and more mineral parts of the lake littoral. The differences between the phytocoenoses of $S$. denticulatum and $W$. exannulata may be due to the interaction of floating mats formed by various species of mosses with their substrates, particularly the deposition of a specific phytomass by the two dominating species of mosses. The interaction of mosses and their substrates was described by Jaynes and Carpentier (1986) and Dierssen (1998).

The results obtained in the present study indicate that the phytocoenoses of the studied mosses are distinct with respect to their floristic composition and occupy a specific position in the littoral of the Lobelia lakes (deep waters of the littoral zone), where they form dense meadows. The above phytocoenoses should, therefore, be classified as dis- 
tinct associations (Sphagnetum denticulati and Warnstorfietum exannulatae) in the system of aquatic communities (Class: Utricularietea intermedio-minoris). In addition they could be good indicators of habitat conditions in deep waters of the littoral zone of Lobelia lakes.

\section{LITERATURE CITED}

ARTS G.H.P. 1990. Aquatic bryophyta as indicators of water quality in shallow pools and lakes in The Netherlands. Ann. Bot. Fennici 27: 19-32.

ARTS G.H.P. 2002. Deterioration of atlantic soft water macrophyte communities by acidification, eutrophication and alkalinisation. Aquat. Bot. 73: 373-393.

ARTS., G.H.P., BUSKENS R.F.M. 1998. The vegetation of softwater lakes in The Netherlands in relation to human influence and restoration measures, with special attention to the association Isoëto-Lobelietum. Mitt. Arbeitsgem. Geobot. in Schleswig-Holstein u. Hamburg 57: 111-120.

ARTS G.H.P., VAN DER VELDE G., ROELOFS J.G.M., VAN SWAAY C.A.M. 1990. Successional changes in the soft-water macrophyte vegetation of (sub)atlantic, sandy, lowland regions during this century. Freshwater Biol. 24: 287-294.

BANAŚ K. 2002. Impact of humic substances on Sphagnum denticulatum habitats. Acta Soc.Bot.Pol. 71: 63-69.

BOIŃSKI M., BOIŃSKA U. 1988. Roślinność jezior lobeliowych okolic Strugi Ośmiu Jezior (Bory Tucholskie). Acta Uniw. Nicolai Copernici, Ser. Biol. 29, 63: 53-77. (in Polish)

BRANDRUD T.E., JOHANSEN S.W. 1994. Effects of acidification on macrophyte growth in the humex Lake Skjervatjern, with special emphasis on Sphagnum auriculatum. Environ. Int. 20: 329-342.

CEYNOWA M., REJEWSKI M. 1969. Roślinność jeziora Nawionek. Studia Soc. Sc. Torun., Sec. D, 9: 1-16. (in Polish)

DĄMBSKA I. 1965. Roślinność litoralu jezior lobeliowych Pojezierza Kartuskiego. PTPN, Prace Kom. Biol. 30: 1-53. (in Polish)

DIERSSEN K. 1998. Die Isoetiden-Story: Oligotrophe Gewässer, Anpassungen der Isoetiden und Veränderungen der Standorte in der jüngsten Zeit. Mitt. Arbeitsgem. Geobot. SchleswigHolstein u. Hamburg 57: 53-66.

EVANS L.S. 1984. Botanical aspects of acidic precipitation. Bot. Rev. 50: 449-490.

GOS K., BOCIĄG K., BANAŚ K. 1998. Roślinność podwodna w kwaśnych jeziorach Pomorza. In: Park Narodowy Bory Tucholskie. Banaszak J., Tobolski K. (eds). Wydawnictwo Uczelniane WSP w Bydgoszczy, pp. 261-278. (in Polish)

GOS K., BANAŚ K. 1999. Succession trends of submerged vegetation in Pomeranian acidic lakes (NW Poland). Acta Hydrobiol. 41: 171-178.

GRAHN O. 1977. Macrophyte succession in Swedish lakes caused by deposition of airborne substances. Water Air Soil Pollut. 7: 295-305.

JAYNES M.L., CARPENTER S.R. 1986. Effects of vascular and nonvascular macrophytes on sediment redox and solute dynamics. Ecology 67: 875-882.

KARTTUNEN K., TOIVONEN H.1995. Ecology of aquatic bryophyte assemblages in 54 small Finnish lakes, and their changes in 30 years. Ann. Bot. Fennici 32: 75-90.

KOCHLER A., SCHOEN R. 1984. Versauerungsresistenz submerser Makrophyten. Erste Ergeb. Mater. 1/84: 353-364.

KRASKA M., PIOTROWICZ R. 1994. Roślinność wybranych jezior lobeliowych na tle warunków fizyczno-chemicznych ich wód. In: Jeziora lobeliowe, charakterystyka, funkcjonowanie i ochrona. Część 1. Kraska M. (ed.). Idee ekologiczne 6, ser. Szkice, 4: 67-83. (in Polish)

KRASKA M., PIOTROWICZ R., KLIMASZYK P. 1998. Cechy fizyczno-chemiczne wód jezior lobeliowych wraz z charakte- rystyką roślinności makrofitowej. In: Park Narodowy Bory Tucholskie. Banaszak J., Tobolski K. (eds). Wydawnictwo Uczelniane WSP w Bydgoszczy, pp. 197-211. (in Polish)

KRASKA M., PIOTROWICZ R., RADZISZEWSKA R. 1999. Dystrophication as the chief factor of changes in the physicochemical properties of water and vegetation of lobelian lakes of the Bory Tucholskie National Park (NW Poland). Acta Hydrobiol. 41: 127-135.

KRASKA M., RUSIŃSKA A. 1998. Drepanocladetum tenuinervi Kraska \& Rusińska 1998 ass. nova. w jeziorach Pojezierza Pomorskiego. Warunki występowania. Mat. Symp. i obrad sekcji 51 Zjazdu PTB: 245. (in Polish)

KREŃSKA B. Roślinność naczyniowa jeziora Otalżyno i jeziora Kamień na Pojezierzu Kaszubskim. Ba. Fizjogr. Pol. Zach., Ser. Biol. 24: 159-180. (in Polish)

MALME L. 1978. Floristic and ecological studies of bryophytes in some Norwegian inland waters. Norwegian J. Bot. 25: 271-279 .

MATUSZKIEWICZ W. 2001. Przewodnik do oznaczania zbiorowisk roślinnych Polski. Wyd. Nauk. PWN, Warszawa 537 pp. (in Polish)

NILSSEN J.P. 1980. Acidification of the watershed in southern Norway and some characteristics of acidic aquatic environments. Int. Rev. Ges. Hydrobiol. 65: 177-207.

RAVEN P.J. 1988. Occurrence of Sphagnum moss in the sublittoral of several small oligotrophic lakes in Galloway, Southwest Scotland. Aquat. Bot. 30: 323-330.

REJEWSKI M. 1981. Roślinność jezior rejonu Laski w Borach Tucholskich. Rozprawy UMK, Torun, 178 pp. (in Polish)

ROBERTS D.A., SINGER R., BOYLEN C.W. 1985. The submerged macrophyte communities of Adirondack lakes (New York, USA) of varying degrees of acidity. Aquat. Bot. 21: 219-235.

ROELOFS J.G.M. 1983. Impact of acidification and eutrophication on macrophyte communities in soft waters in The Netherlands. 1. Field studies. Aquat. Bot. 17: 139-155.

SÖRENSEN H. 1948. Studies of the ecology of danish water and bay mosses. Dansk. Bot. Ark 12: 19-47.

SZAŃKOWSKI M. 1998. Ekologiczny status roślinności jezior lobeliowych w Polsce. Wydz. Biol. UW, mscr. 1455 pp. (in Polish)

SZAŃKOWSKI M., KŁOSOWSKI S. 1996. Habitat variability of the phytocoenoses of Isoëto-Lobelietum in Poland. Fragm. Flor. Geobot. 41: 255-267.

SZMEJA J., CLÉMENT B. 1990. Comparaison de la structuree et du déterminisme des Littorelletea uniflorae en Poméranie (Pologne) et en Bretagne (France). Phytocoenologia 19: 123-148.

SZMEJA J. 1994. An individual's status in populations of isoetid species. Aquat. Bot. 48: 203-224.

SZMEJA J. 1997. Specyfika i zagrożenia jezior lobeliowych w Polsce. In: Fałtynowicz W., Latałowa M., Szmeja J. (eds). Dynamika i ochrona roślinności Pomorza. Bogucki Wyd. Nauk., Gdańsk-Poznań: 83-90. (in Polish)

SZMEJA J., BAZYDŁO E., URUSKA A. 2001. Role of humic substances in the determination of Sphagnum denticulatum Brid. and Myriophyllum spicatum L. habitat conditions. Pol. J. Ecol. 49: 101-113.

TER BRAAK C.J.F., ŠMILAUER P. 1998. CANOCO Reference Manual and User's Guide to Canoco for Windows. Software for Cannonical Community Ordination (version 4). Centre for Biometry Wageningen (Wageningen, NL) and Microcomputer Power (Ithaca Ny, U.S.A.): 352 pp.

VÖGE M. 1988. Tauchuntersuchungen der submersen Vegetation in skandinavischen Seen unter Berücksichtigung der Isoetiden Vegetation. Limnologica 19: 89-107.

ZAR J.A. 1984. Biostatistical Analysis. Prentice-Hall, Inc., Englewood Cliffs. New Jersey, 718 pp. 